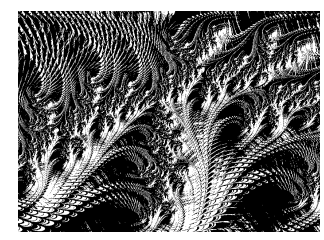

https://doi.org/10.5559/di.30.4.01

\title{
JOB AND ORGANISATIONAL LEVEL ASPECTS OF WORK IN SLOVENIA
}

Ana ARZENŠEK, Suzana LAPORŠEK

Faculty of Management, University of Primorska, Koper, Slovenia

Valentina FRANCA

Faculty of Public Administration, University of Ljubljana, Ljubliana, Slovenia

UDK: $331.1(497.4)$

Original scientific paper

Received: February 24, 2020

Marginalised groups of workers in Slovenia are traditionally most affected by labour market uncertainty, but increasingly middle-class and upper-class workers are experiencing the same. Furthermore, new work forms have given rise to ethical, psychological and legal dilemmas. In this paper, we examine the concept of decent work and focus on job-related and organisational aspects of work in Slovenia. In the empirical part of the paper we therefore focus on working time, work organisation and co-operation within teams, work-life balance, health and stress, and overall satisfaction with working conditions. Our results evidence that new work forms increase insecurity and consequently diminish worker well-being; and this is most experienced by younger, agency and self-employed workers in Slovenia. This suggests that the development of multilevel and multifaceted measures which take into account socio-psychological and legislative factors to address labour market segmentation is necessary, especially when addressing the needs of those forced to work atypically.

Keywords: decent work, organisational psychology, quality of employment, labour market situation, Slovenia

Ana Arzenšek, University of Primorska,

Faculty of Management, Izolska vrata 2, 6101 Koper, Slovenia. 
Slovenia's path to capitalism was mapped out by its social and institutional reform in the mid-1990s. The loss of the Yugoslavian and Eastern European markets, the opening of goods, money and labour markets, and the collapse of larger economic powers, led Slovenia to the bottom of its economic crisis in 1992. Since then, the Slovenian economy has steadily grown, and its shift of focus to mostly western markets has resulted in higher productivity and wage growth. During this time, the demand for improved social protection repeatedly conflicted with the ideas of those in favour of a more radical liberalisation of markets, and labour and employment legislation gradually reduced employee protection. Employee protection had previously been characterised by relatively strong unions and social partner negotiation (Svetlik, 2004), but the economic crisis in 2009 led to further slackening in such protection and working-condition flexibilisation in many European countries, including Slovenia. Moreover, the end of the crisis did not put an end to sustainable employment loss (International Labour Organization, 2018).

Increases in temporary, contract and low-wage jobs, and underemployment and unemployment have traditionally and negatively most affected marginalised groups of workers, but recently white-collar and intellectual workers have been experiencing the same: labour market conditions affect individual and social group well-being, including decent work opportunity. As a consequence, significant international academic and professional attention, including that of the International Labour Organization (ILO), has been devoted to the concept of decent work in the last two decades. Most discussion stems directly from the ILO's definition of decent work, which states that decent work offers opportunities for productive work with fair payment, job and social security, better opportunities for personal growth, social inclusion, freedom to express concern, and association and participation in decision-making that positively affects equal opportunities and equal treatment (International Labour Organization, 2017). Pursuant to this, four components of decent work are elaborated: employment, social protection, workers' rights and social dialogue (Ghai, 2003). Although authors' opinions differ (Di Fabio \& Maree, 2016; Blustein et al., 2019), it is crucial to interpret decent work according to the current economic and social situation as suggested by Ferraro et al. (2016). Thus, we posit that decent work is not solely linked to certain forms of work, although it is indisputable that some forms, namely precarious ones, lead individuals to worse labour market positions (Kenner et al., 2019). Although there is no single definition of precarious work, it is associated with atypical forms and their negative consequences for the functioning of indi- 
DRUŠ. ISTRAŽ. ZAGREB GOD. 30 (2021), BR. 4, STR. $655-674$

ARZENŠEK, A. ET AL.: JOB AND... viduals, society and the labour market. The standard employment relationship, described as a full-time and permanent contract of employment between employee and employer, is considered as a norm or benchmark, against which other forms are to be compared when implementing the principle of equal treatment (Deakin, 2016).

As decent work is a complex concept, referring to various dimensions of work, a common methodological framework is crucial for its applicability. Despite ILO's several attempts, there is still no universal methodology or guidance for measuring decent work, mostly due to the lack of consensus on what constitutes a good job, ${ }^{1}$ and, relatedly, shortage of relevant data. Empirical literature, therefore, often focuses on different aspects of quality of work, quality of employment, quality of job or precarious work, which are considered to be more easily measured (Burchell et al., 2014; Piasna et al., 2020). As Green (2021) notes, although often perceived as similar, there is a distinction between the concepts of quality of work and employment (QWE), decent work and job quality - the QWE concept covers both decent work and job quality; the concept of decent work is a society-level concept, whereas the concept of job quality refers to characteristics of a job which are held to meet worker's needs. The concept of decent work therefore encompasses universal rights, job quality and subjective well-being of work (Conigliaro, 2019).

In this paper we focus on job and organisational aspects of work in Slovenia, which can be considered as an important component of decent work. Due to lack of common methodology, we measure the studied components by using the selected variables from the sixth wave of the European Working Conditions Survey (EWCS) data, which is in empirical literature also often used as a measure of job quality (Green, 2021). In addition, we suggest how to better facilitate access to decent work.

The structure of this paper is as follows. Section 2 presents the literature review on psychological perspectives regarding decent work, focusing on job-related and organisational level components. Section 3 provides an overview of methodology and data, and Section 4 presents empirical findings. The last section provides the discussion of findings and conclusions.

\section{LITERATURE REVIEW}

Work is of great value as it provides income to satisfy existential and social needs, including affiliation, and the need for personal growth. Labour market uncertainty and poor working conditions diminish the fulfilment of these needs, resulting in frustration and dissatisfaction with job. Individuals eva- 
DRUŠ. ISTRAŽ. ZAGREB GOD. 30 (2021), BR. 4, STR. 655-674

ARZENŠEK, A. ET AL.: JOB AND... luate their job and work situation with respect to different characteristics, among which job-related and organisational factors present an important part. Below we present an overview of empirical literature on job-related and organisational aspects of work and an overview of empirical studies for Slovenia.

\section{Job-related components}

Decent pay, job security, paid holidays and sick leave, and safe working environments free from mental and physical risk or harm, are considered key features of decent work according to a study of low-paid workers by Stuart et al. (2016). In line with this, Stuart et al. (2016, p. 4) define decent pay as "an hourly rate or salary that is enough to cover basic needs such as food, housing and things most people take for granted, without getting into debt". With this in mind, decent pay need not only cover basic needs but also be adequate for active participation in society, such as buying a present for a friend. Moreover, indecent levels of management pay tell workers they are of little value to said management.

Even so, individuals not only do their job because it represents a source of income, they also gain well-being and meaning (Judge et al., 2010). According to Frankl (1969), work tasks are meaningful when individuals associate them with a higher purpose, such as serving society or meeting a goal. Autonomy, work-identity congruence, professional growth opportunity, task significance, and amount of work (Lysova et al., 2019) are also sources of meaning; conversely, job demand and worker qualification incongruence do not provide meaning nor facilitate decent work provision.

Stuart et al. (2016) rated job security as the second most important component of decent work in their study; having a secure and permanent contract is important for life stability and predictability. From a psychological perspective, job insecurity evokes considerable distress; it further affects the capacity to cope with stress and manage contemporary life demands (Blustein et al., 2019; Duffy et al., 2016; Kinnunen et al., 1999). Work-related uncertainty is concerned with employment continuity, including the prospect of involuntary job loss (Heaney et al., 1994).

Possible change in working conditions and career opportunities also increase uncertainty. Sverke et al. (2002) meta-analytically identified how workplace uncertainty is related to attitudes towards work, organisation, health and behaviour. They analysed 72 studies incorporating 38,531 workers and found that workplace uncertainty negatively affected all aspects of functioning, including eliciting negative attitudes towards work and organisation, significant deterioration in health 
DRUŠ. ISTRAŽ. ZAGREB GOD. 30 (2021), BR. 4, STR. 655-674

ARZENŠEK, A. ET AL.: JOB AND... and efficiency, and increased intention to leave organisations. These negative effects were markedly so for manual workers, who were less efficient and exhibited higher intention to leave organisations, so organisations employing larger proportions of such workers face greater potential loss in efficiency and trust (Sverke et al., 2002).

Paid holidays and sick leave also affect work-life balance. Allowing sufficient rest, especially in cases of sickness, or the ability to be unemployed without having to worry about covering life's costs, importantly affect our sense of protection and value. For many people working in precarious work environments, paid holidays and sick leave are unfulfilled expectations. Stuart et al. found this the third most important decent work component in their related study (Stuart et al., 2016).

The broad concept of safe working environment was found to be the fourth most important decent work component in the same study. A safe working environment is one free from mental and physical risk or harm (Mauno et al., 2001). Safety pertains to physical, such as safety equipment, and psychosocial conditions, such as a bullying-free environment. Other studies (Duffy et al., 2017; Lysova et al., 2019) also support the notion that working in safe and just conditions is a decent work component.

\section{Organisational components}

Respectful managers are supportive, considerate and encourage workers to do their jobs well (Judge et al., 2004), they praise good work, give prompt feedback for enhancing efficiency, and are aware of employee work-life balance and personal need. Stuart et al. (2016) report respecting workers, including communicating clearly and acknowledging achievement, as the fifth most important factor amongst the participants in their decent work study. These managerial characteristics, together with the capacity to inspire, set high goals and are seen as a model of integrity closely linked to transformational leadership and other popular concepts, such as ethical and empowering leadership. Other studies indicate that transformational leadership is a cornerstone of decent work (Avolio et al., 2004; Judge et al., 2004; Lysova et al., 2019).

According to Schein (2010), organisational culture is a set of shared values, beliefs and assumptions on how things are done and should be done on a daily basis in an organisation. Which organisational cultures enable the provision of decent work? According to Lysova et al. (2019), cultures that foster innovation support and ethically enhance meaning and well-being. Furthermore, hierarchy is negatively correlated to meaningful work perception (Lysova et al., 2019). Consequently, 
DRUŠ. ISTRAŽ. ZAGREB GOD. 30 (2021), BR. 4, STR. 655-674

ARZENŠEK, A. ET AL.: JOB AND... human resource recruitment and selection practice needs to be congruent with organisational culture, including human resource and line managers understanding worker ability, task alignment (Person-Organisation fit) and broader purpose.

Other HRM practices, such as socialisation and career development, are also integral to the provision of decent work; individuals who experience a lack of personal growth or career development are less likely to perceive decent work (Arnoux-Nicolas et al., 2016). Individuals need sufficient human and material resources to work successfully. Thus, organisations should ensure resource sufficiency, work task and qualification fit, and opportunities for decent work (Sehnbruch et al., 2015).

Additionally, good workplace relationships and positive climate are important characteristics of decent work. For example, Colbert et al. (2016) found that opportunities to support, assist, mentor, or care for another worker foster positive relationships and help create supportive work environments.

\section{Empirical findings for Slovenia}

There are only a few studies for Slovenia that analyse job-related and organisational factors, mostly in the perspective of quality of employment and focusing on specific groups. For example, Tomaževič et al. (2014) examined the effect of demographic, job-related and organisational factors on employee satisfaction in the police service, and proved that organisational factors, i.e. supervision, support and trust had the strongest effect on employee satisfaction, and that salary and security had the weakest. Aristovnik and Jaklič (2013) focused on older workers and proved them to be relatively dissatisfied with working conditions when compared to the EU average, which might influence their retirement decisions. Based on a sample of large Slovenian companies, Hvalič-Touzery et al. (2020) found that working conditions are correlated with employees' general psychological well-being. A recent study by Domadenik et al. (2020) about precarious work concluded that precariousness' characteristics are perceived in all forms of work, differing only in degree.

\section{METHODOLOGY AND DATA}

In this paper we focus on job-related and organisational aspects of work, being an important constituent of the decent work concept. Due to the lack of methodological guidelines on measuring decent work and its components (see Piasna et al., 2020; Green, 2021), our framework for analysing the job-related and organisational factors relies on existing empirical literature and availability of data for Slovenia. According to the empirical literature (Kozan et al., 2019; Lysova et al., 2019; United Nations, 2015; Tomaževič et al., 2014; Johnson, 2012), there are five job-related and organisational aspects of work 
DRUŠ. ISTRAŽ. ZAGREB GOD. 30 (2021), BR. 4, STR. 655-674

ARZENŠEK, A. ET AL.: JOB AND...

(1) FIGURE 1

Overview of used variables that have significant impact on employee satisfaction and thus may be considered as an important element of job quality and decent work: working time, work organisation and co-operation in teams, work-life balance, health and stress, and working condition satisfaction. We study each of the five components by analysing several variables, as presented in Figure 1. The analysis is based on the most recent data from the sixth wave of the European Working Conditions Survey (EWCS) from $2015,{ }^{2}$ which measures the working conditions of employees and the self-employed across Europe (EWCS, 2020). In 2015, the sample for Slovenia included 1,607 respondents, of which $86 \%$ were employees and $14 \%$ self-employed.
Working time:

- Actual and desired number of hours worked

- Working time stability

- Request to come to work at short notice

- Setting of working time

Work organisation and

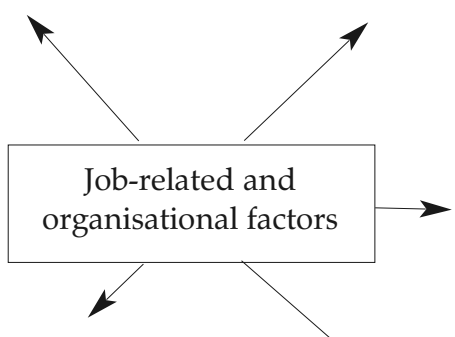

co-operation in teams:

- Trust of management to workers

- Co-operation with colleagues

- Recognition of good work

- Right to take a break

- Sufficient time to complete work

- Inclusion of worker's idea to work

- Perception of fair treatment
Work-life balance:

- Fit of working hours to family and social commitments

- Work and household jobs

- Worrying about job when not working

- Work and time for family

- Work in free time to meet work demands

- Family responsibilities and time and concentration on work

Health and stress:

- Health or safety at risk due work

- Impact of work on health

Working conditions:

- Overall satisfaction with working conditions

- Appropriate pay

- Prospects for career advancement

- Recognition of work

- Relations with colleagues

- Motivation at work

\section{RESULTS OF EMPIRICAL ANALYSIS}

In this section we assess the job-related and organisational aspects of work, relying on the components and variables presented in Figure 1. Prior to the presentation of various aspects of work, we shortly present an overview of the labour market situation in Slovenia, understanding of which is also important for the further shaping of policy recommendations. 


\section{Labour market developments in Slovenia}

The employment rate in Slovenia has significantly increased over the past two years, well above the EU average: the employment rate for the age group 20-64 years in 2018 in Slovenia was $75.4 \%$, which was 2.3 percentage points above the EU-28 average and 8.2 percentage points above its low of $67.2 \%$ in 2013, due to the effects of the global financial crisis (Eurostat, 2020).

The Slovenian labour market is highly segmented in terms of permanent and fixed-term contracts workers, and younger workers more often hold fixed-term contracts. Although the 2013 Employment Relations Act introduced important changes to reduce segmentation and increase labour market flexibility to increase the probability of permanent contract offer, especially for first-time entrants (Vodopivec et al., 2016), the problem of segmentation remains: the average incidence of fixed-term contracts in Slovenia in 2018 was 11.7\%; among 15 to 24 -year-olds it was $40 \%$, with only $5.7 \%$ of older workers, 55 to 64 years of age, holding fixed-term contracts. On the other hand, part-time employment, another form of atypical employment, has been rather low at a rate of only $7 \%$ of total employment in 2018 (SORS, 2020). This can also be attributed to Slovenia's high rate of participation of women on the labour market: Slovenia shows the highest participation rate for women aged 35-44 in the EU at over 85\%.

With the growth of new work forms in recent years, the problem of labour market segmentation in Slovenia has gained new dimensions. Even though employees with standard employment contracts predominated (see Table 1), other workers represented 19\% of the working population in 2016; of those, $7 \%$ were individual entrepreneurs, $4.3 \%$ were farmers and family assistants, $3.3 \%$ students, $2.7 \%$ worked for their own firms, and $1.1 \%$ worked under civil contract or for direct payment. Between 2008 and 2016, the increase in working population share was highest for sole entrepreneurs at a rate of $2.2 \%$.

A more detailed analysis of new work form development points to a remarkable increase in the number of self-employed not employing others, their number increasing by $65 \%$ between 2008 and 2016. The increase in share of the self-employed, not including farmers, reached $73.2 \%$ in 2016 , which is 13.6 percentage points higher than in 2008. Furthermore, $26.5 \%$ of this group worked mainly for one client in 2016, with more than half mainly on the premises of said client. The numbers of these two groups of sole entrepreneurs have steadily increased in recent years. The number of sole entrepreneurs working mostly for one client increased by $65.2 \%$ between 2012 and 2016, while the number of sole entrepre- 
neurs working mostly for one client at their premises increased by $82.8 \%$. It can be assumed that many of these cases represent disguised employment relationships.

\begin{tabular}{lccccccccc}
\hline & 2008 & 2009 & 2010 & 2011 & 2012 & 2013 & 2014 & 2015 & 2016 \\
\hline $\begin{array}{l}\text { Employed in employment } \\
\quad \text { relationships }\end{array}$ & 80.5 & 78.5 & 77.0 & 77.9 & 79.3 & 78.2 & 77.0 & 78.7 & 81.0 \\
$\quad \begin{array}{l}\text { Single-member private } \\
\quad \text { limited liability companies }\end{array}$ & 1.7 & 2.6 & 3.2 & 2.6 & 2.2 & 2.5 & 2.3 & 2.5 & 2.7 \\
$\quad \begin{array}{l}\text { Sole entrepreneurs } \\
\text { Independent professions }\end{array}$ & 4.8 & 4.9 & 5.5 & 6.2 & 6.2 & 6.4 & 6.9 & 7.4 & 7.0 \\
$\quad$ Student work & 0.3 & 0.3 & 0.4 & 0.3 & 0.3 & 0.4 & 0.3 & 0.3 & 0.3 \\
$\quad$ Work under civil contract & 4.2 & 3.8 & 4.0 & 3.6 & 3.0 & 3.1 & 2.8 & 3.1 & 3.3 \\
$\quad$ & & & & & & & & & \\
$\quad$ or for direct payment & 0.9 & 1.2 & 1.2 & 1.3 & 1.2 & 1.5 & 1.2 & 1.2 & 1.1 \\
Public work & 0.2 & 0.2 & 0.3 & 0.2 & 0.3 & 0.3 & 0.4 & 0.4 & 0.3 \\
Farmers and family assistants & 7.4 & 8.4 & 8.4 & 7.7 & 7.5 & 7.6 & 9.1 & 6.4 & 4.3 \\
\hline
\end{tabular}

(1) TABLE 1

Structure of working population by work form between 2008 and $2016(\%)$
Note: Calculations are based on Labour Force Survey data obtained from the Statistical Office of the Republic of Slovenia (SORS, 2017). Data were accessed and processed in the safe room at SORS.

Source: SORS, 2017

A similar trend is observed in the number of single-member private limited liability companies without other employees, their number increasing by 79.1\% between 2008 and 2016, their share among all single-member limited liability companies reaching $36.5 \%$ in 2016, which is $5.7 \%$ higher than in 2008 . Of these, only $10.2 \%$ worked for one client and $4.2 \%$ for one client at their premises. As with the self-employed, these cases could represent disguised employment relationships.

\section{Job-related and organisational level aspects of work in Slovenia}

In this section, we analyse job-related and organisational aspects of work in Slovenia through five components: working time, work organisation and co-operation in teams, work-life balance, health and stress, and working condition satisfaction.

\section{Working time}

On average, employed respondents, both in Slovenia and in the EU, work slightly more than they would like to. As seen in Figure 2, the average employee in Slovenia usually works 39.9 hours per week but would rather work 1.2 hours less. In contrast to the EU, there is little difference between actual and desired hours of work per week for self-employed respondents in Slovenia, 37.9 and 37.8 hours, respectively. An analysis by type of employment contract indicates that the difference between actual and desired working hours is highest for workers with permanent contracts, the average amount- 
(1) FIGURE 2

Actual and desired number of working hours, Slovenia and the EÚ-28, 2015 -term contracts would like, on average, to work more hours, although the difference at 0.8 hours per week is rather small, and this is similarly true for other EU countries. Temporary agency workers, both in Slovenia and in the EU, want to work more, with the average difference being 9.8 hours in Slovenia and 4.4 hours in the EU. ${ }^{3}$

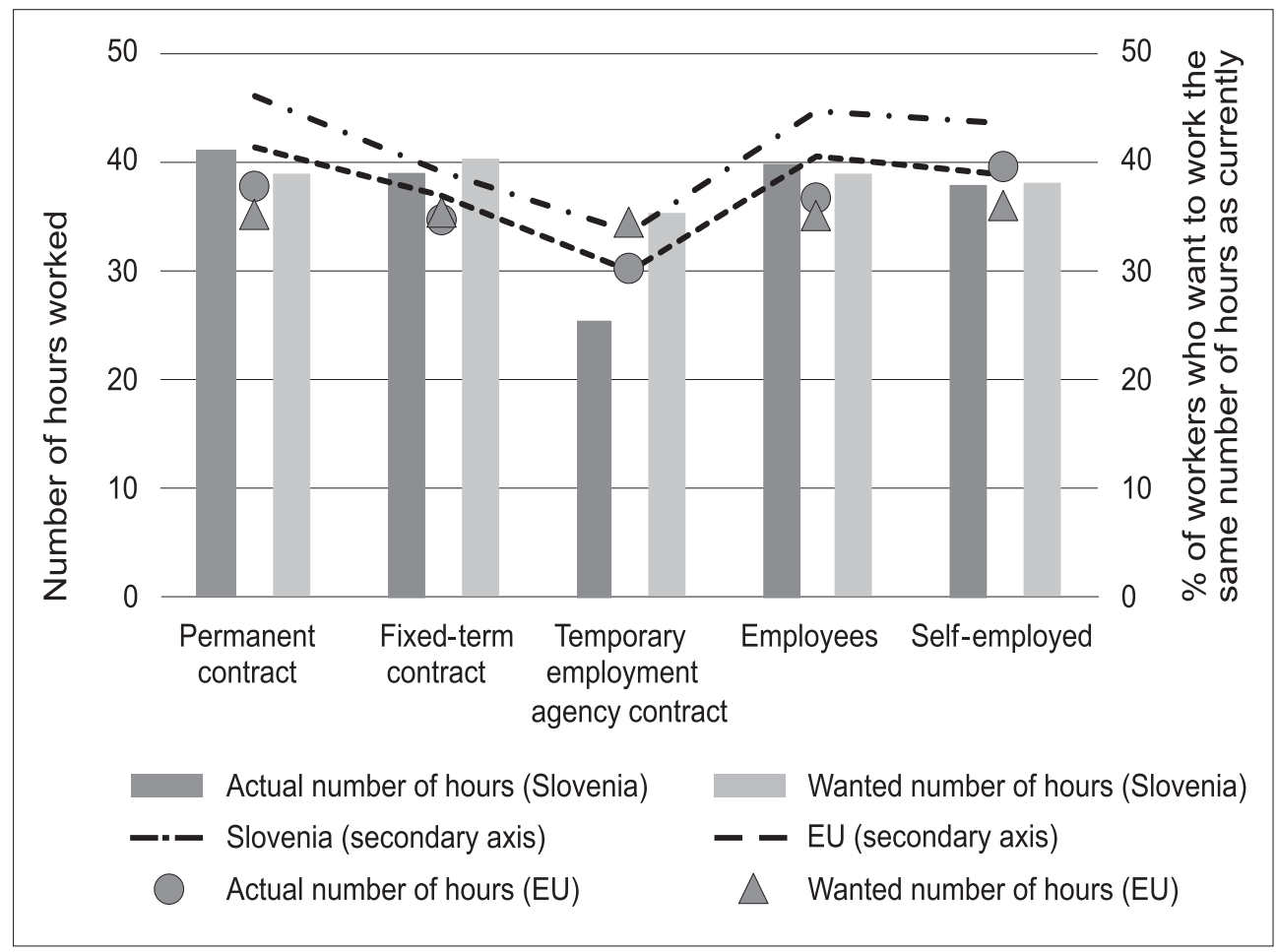

Source: EWCS, 2015

With regard to working time stability, almost $70 \%$ of employed respondents in Slovenia reported that they worked the same number of hours per day or per week, and that their work started and finished at fixed times. Similar findings were observed for the EU. ${ }^{4}$ In contrast, working time stability is significantly lower for self-employed respondents; for example, only $22.8 \%$ of the self-employed in Slovenia reported that they worked the same number of hours per day, with $30.1 \%$ in the EU, and only $18.3 \%$ reported fixed starting and finishing times, with $27.1 \%$ in the EU. Compared to the EU, self-employed respondents in Slovenia recorded significantly lower working time stability, both in terms of working hours/ days and working times. Approximately $10 \%$ of employed respondents in Slovenia reported that they had been requested to work at short notice several times per month.

With regard to working time arrangement, $70 \%$ of employed respondents stated that it was set by the organisation 
DRUŠ. ISTRAŽ. ZAGREB GOD. 30 (2021), BR. 4, STR. 655-674

ARZENŠEK, A. ET AL.: JOB AND...
(1) FIGURE 3

How working hours fit in with family and social commitments, Slovenia, 2015 with no possibility of change. As expected, more than $80 \%$ of self-employed respondents reported that they entirely determined working time.

\section{Work organisation and co-operation in teams}

More than $85 \%$ of those employed in Slovenia believe that management trusts them, $70 \%$ of them stating that they are praised when they have done a good job and over $90 \%$ reporting good cooperation with colleagues; and these findings are comparable to the EU average. About a third of the employed reported that they could nearly always take a break should they wish, which is below the EU average of $40.2 \%$. On the other hand, Slovenia, compared to the EU, records higher shares for those who: always or mostly have sufficient time to complete their work, $80.3 \%$ and $74 \%$ respectively; can include own ideas in their work, $62.1 \%$ and $51.7 \%$ respectively; and know what is expected of them (98\% and $93.2 \%$ respectively). More than $90 \%$ of respondents, both in Slovenia and the EU, always or mostly felt they were treated fairly.

\section{Work-life balance}

On average, Slovenian respondents report good work-life balance. As seen in Figure 3, 76 to $84 \%$ of employed and self-employed respondents reported that their working hours fit well or very well with their family and social commitments, which is comparable to the EU average. With regard to type of employment contract, work-life balance is lowest among respondents with fixed-term contracts.

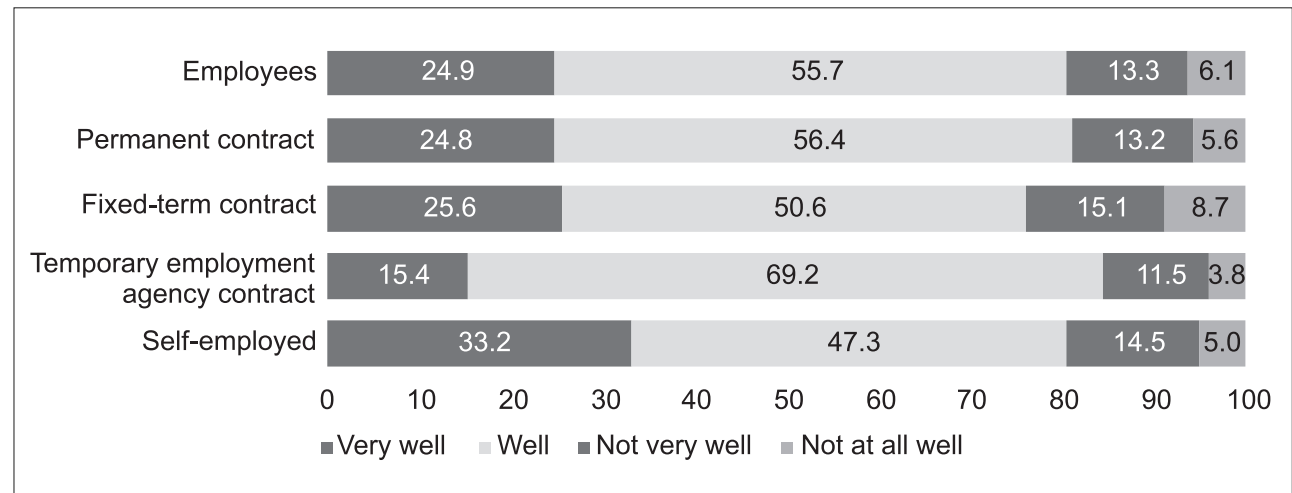

Source: EWCS, 2015

A more detailed analysis of work-life balance shows that: $15.1 \%$ of employed respondents in Slovenia worry about work most of the time when not working, the EU average being $13.3 \% ; 12.4 \%$ often felt too tired after work to do all the necessary household jobs, the EU average being $21 \%$; and $12.7 \%$ felt that their jobs often prevented them from devoting 
DRUŠ. ISTRAŽ. ZAGREB GOD. 30 (2021), BR. 4, STR. 655-674

ARZENŠEK, A. ET AL.: JOB AND...

(1) FIGURE 4 Working in free time to meet work demands, Slovenia, 2015 sufficient time to their families, the EU average being $10.8 \%$. Work-life balance is considerably lower for self-employed respondents, with $24.4 \%$ reporting they worry most of the time about work when not working, the EU average being 26.3\%; $15.3 \%$ report fatigue, the EU average being $23.9 \%$; and $16.9 \%$ report an inability to spend sufficient time with their families because of work, the EU average being $15.2 \%$.

The self-employed also reported working more in their free time; as seen in Figure 4, 34.6\% of self-employed respondents reported they worked in their free time every day or several times a week, which is well above the EU average of $20.2 \%$. In contrast, only $8.9 \%$ of the employed reported that they regularly worked in their free time.

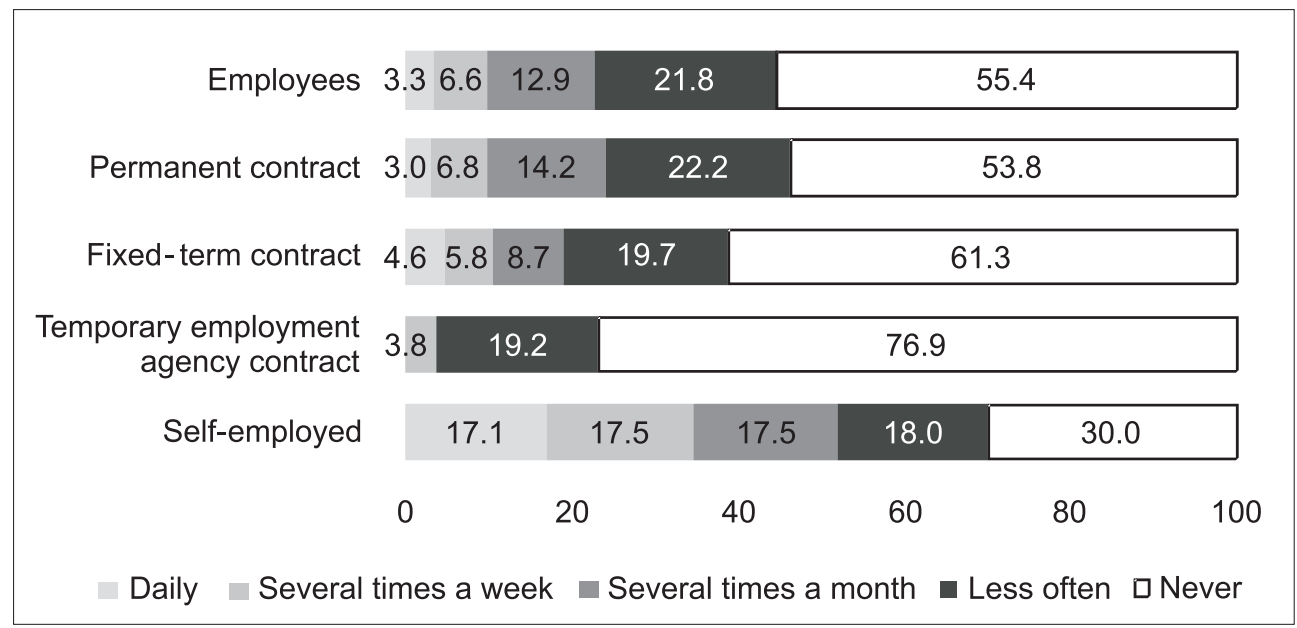

Source: EWCS, 2015

\section{Health and stress}

As seen in Figure 5, 36.8\% of employed respondents in Slovenia believed that health and safety represented work-related risk to them, the proportion of those with permanent contracts higher at $38.2 \%$; the proportion at $35.1 \%$ for the self-employed is a bit lower, yet still much higher than the EU average of approximately $25 \%$. Furthermore, $33.2 \%$ of the self-employed and $40.2 \%$ of the employed believed that work is the main factor affecting their health, which is also above the EU average of $30 \% .^{5}$

Workplace stress is always or in the main experienced by $27.8 \%$ of employed respondents, which is above the EU average of $26.2 \%$. It was more often reported by workers with permanent contracts, $29.9 \%$ in Slovenia and $27 \%$ in the EU; and less so among the self-employed, where $19.1 \%$ experienced stress always or in the main, which was below the EU average of $25 \%$. 
$\rightarrow$ FIGURE 5

Share of workers reporting negative health impact of work, Slovenia, 2015

(1) FIGURE 6

Satisfaction with working conditions, Slovenia and the EU, 2015

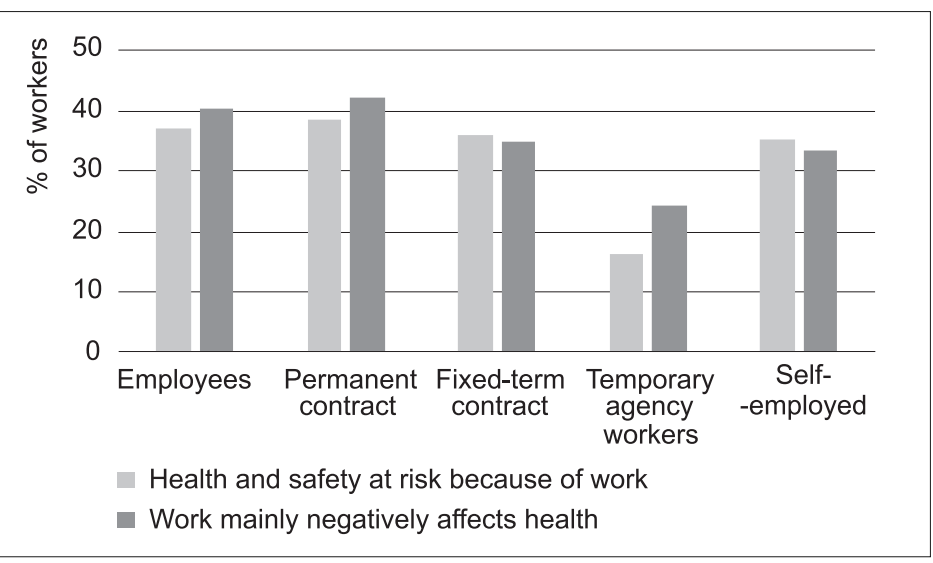

Source: EWCS, 2015

\section{Satisfaction with working conditions}

Over $80 \%$ of the respondents were satisfied or very satisfied with working conditions in Slovenia, which is comparable to the EU. The more detailed analysis presented in Figure 6, nevertheless, points to lower satisfaction with regard to payment, career prospects and recognition, especially among employed respondents. Compared to the EU, Slovenian respondents report significantly lower recognition for their work.

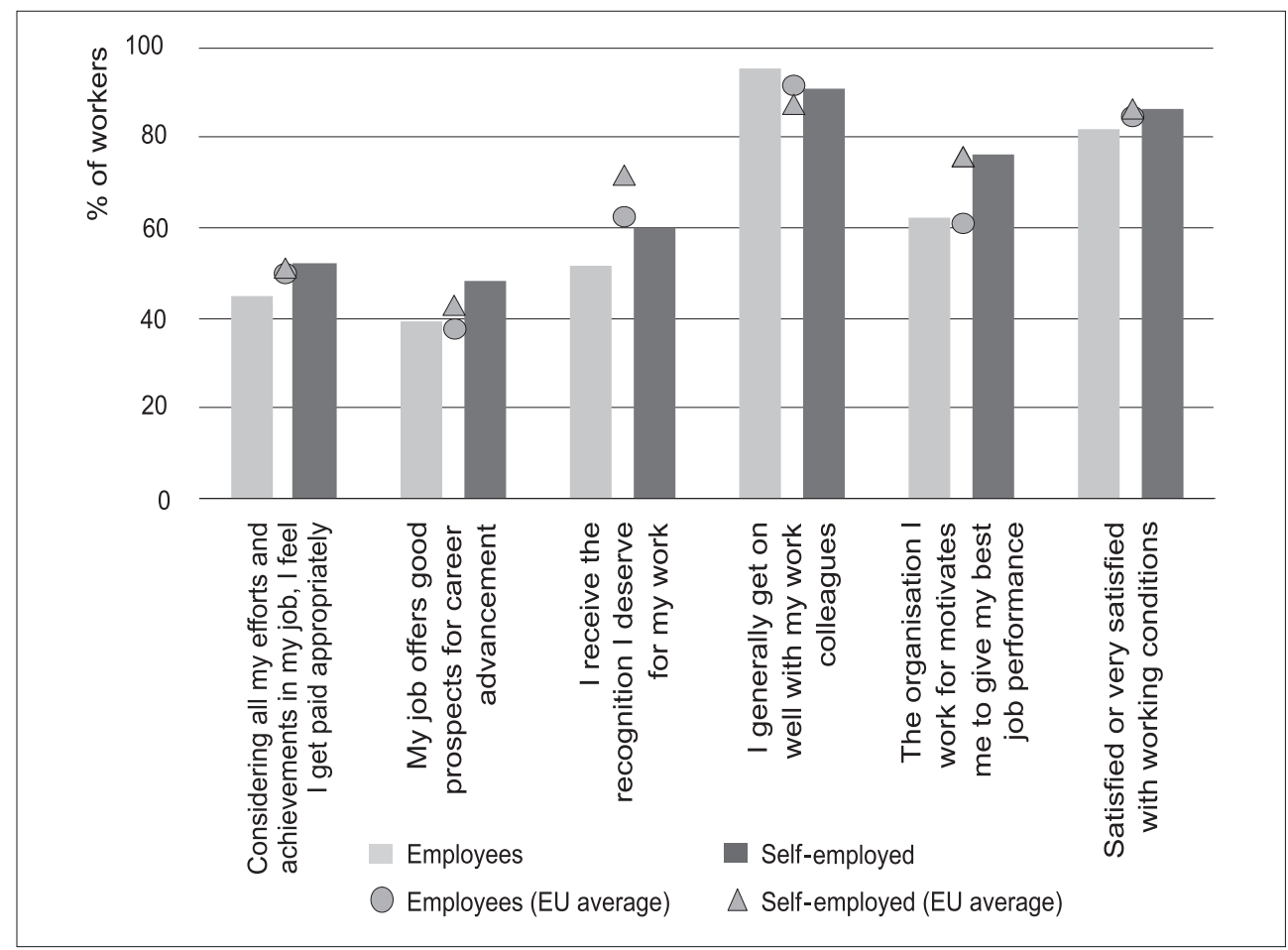

Source: EWCS, 2015 
Even though the employment rate in Slovenia significantly increased, segmentation between workers with permanent and those with fixed-term contracts remains an issue, with younger workers being disproportionally affected. Moreover, Slovenia recorded growth in new work forms in the same period, with a remarkable increase in the number of self-employed not employing any other workers. A sharp increase in single-member private limited liability companies without employees was observed. As with the self-employed, these cases could represent disguised employment relationships.

The increasing trend in instability threatens well-being and this is markedly so for younger workers. Stuart et al. (2016) state that secure and permanent contracts are important determinants of stability and predictability in life. From a psychological perspective, work instability undermines one's sense of security, evoking considerable distress. At the same time, job insecurity affects our ability to cope with stress and manage contemporary life demands (Blustein et al., 2019; Duffy et al., 2016; Kinnunen et al., 1999).

With regard to number of hours worked and to working time stability, it can be seen that agency workers and self-employed workers in Slovenia experience lower work quality. Agency workers especially work more than 40 hours per week, probably to ensure financial security for their families. Compared to the EU, the self-employed in Slovenia reported significantly lower levels of working time stability, both in terms of working hours/days and working times. Around one tenth of employees in Slovenia reported they had regularly been requested to work at short notice. Furthermore, over two thirds of employed respondents stated that working time arrangements were set by the organisation with no possibility of changes.

In Psychology of Working Theory (PWT), Duffy et al. (2016) focus on the experiences and needs of workers, including workers with limited control over their career choices, by investigating the role played by psychological, economic and contextual factors in terms of career development opportunities as components of decent work, a key finding being that physiological needs, such as sufficient rest, are important components of decent work. Consequently, agency and self-employed workers without stable worktime arrangements and sufficient time to rest between working days/hours are less likely to experience decent work.

The situation in Slovenia is better with regard to work organisation and co-operation in teams. The majority of respondents reported that their management trusted them and 
DRUŠ. ISTRAŽ. ZAGREB GOD. 30 (2021), BR. 4, STR. $655-674$

ARZENŠEK, A. ET AL.: JOB AND... showed appreciation when they had done a good job. A majority also reported good cooperation with colleagues; more than $60 \%$ stated they could include their own ideas in their work; $98 \%$ knew what was expected of them; and over $90 \%$ thought they were treated fairly. Based on this, the majority of participants worked for organisations with supportive cultures. Being respectful to workers, trusting them, clear communication, acknowledgment and giving them opportunity to express their ideas are components of decent work and important indicators of corporate social responsibility (Schein, 2010; Lysova et al., 2019).

In general, Slovenian respondents reported good work-life balance, the lowest rates being among respondents with fixed-term contracts and the self-employed, among whom, a considerable proportion worried about work most of the time, even when not working, or often felt too tired after work to do all their household chores or devote sufficient time to their families. The self-employed reported that they regularly worked in their free time at a level well above the EU average. According to Stuart et al. (2016), not having to worry about existential costs while unemployed importantly and positively affects our sense of protection and value. Decent work deficit exists for a considerable proportion of Slovenes.

In comparison to the EU average, Slovenes with permanent contracts and those self-employed believed that work negatively affects their health and safety. Moreover, the incidence of workplace stress was higher than in the EU, especially for workers on permanent contracts. Chronically high levels of work stress might indicate unsuitable working conditions.

The majority of respondents in Slovenia were satisfied with their working conditions. However, lower levels of satisfaction with regard to payment, career prospects and recognition, especially among employees, existed. Compared to the EU, Slovenian respondents reported significantly lower levels of work recognition.

It is suggested that organisations invest more in strategic human resource management, more precisely, in contemporary leadership practice focused on employee development (Lysova et al., 2019) to increase employee engagement and autonomy. Furthermore, organisations in Slovenia should better develop organisational cultures that foster innovation and enhance belonging and meaning. In line with this, organisations should invest in educational programs to understand stress patterns and in stress management workshops for their employees.

Secondly, it is difficult for management to assess worker well-being, working condition satisfaction and stress at work 
DRUŠ. ISTRAŽ. ZAGREB GOD. 30 (2021), BR. 4, STR. 655-674

ARZENŠEK, A. ET AL.: JOB AND... if no ongoing, prompt, sufficient and reliable internal communication system is integrated in the corporate culture. In terms of developing such a culture, companies are advised to integrate their internal communication with everyday leadership practice, because sporadic opportunities for information exchange, such as annual interviews, are insufficient. Managements are also advised to act if working conditions are not decent.

In terms of policy change, we suggest the development of multifaceted measures to address labour market segmentation. Socio-psychological and legislative factors need to be taken into account, especially when addressing the needs of those forced to work atypically. Moreover, health and safety, and career development are also decent work components. Thus, a multilevel approach needs to be taken and appropriately implemented in line with Slovenian and European labour market specifics.

Our study has some shortcomings. Firstly, we examined working condition quality based on data for 2015, the most recent EWCS data, with a sample size of 1,600 , so it is limited with regard to generalisation. Secondly, we only included a limited number of job and organisational variables in our analysis because of paper length restrictions. Finally, we should have also shone a light on cultural level components of decent work such as those proposed in PWT.

In future research, we will also focus on corporate social responsibility (CSR) and decent work. CSR is the responsibility of organisations to society, to all of their stakeholders, not just shareholders (Wang et al., 2016). CSR towards employees is a prerequisite of decent work (Şahin \& Bayramoğlu, 2015) implemented, for example, through HR practices that are ethical and focused on employee development and engagement (Lysova et al., 2019). To provide a more in-depth analysis of decent work in Slovenia, we will also take better and broader human resource practice into account.

\section{NOTES}

${ }^{1}$ An in-depth overview of operationalisation and measurement issues of decent work is available in Piasna et al. (2020).

2 Slovenia participates in the EWCS since 2001.

${ }^{3}$ The results for agency workers for Slovenia should be interpreted with caution due to small sample size (26 respondents).

${ }^{4}$ Analysis by type of employment contracts points to considerably lower working time stability for agency workers - only one-third of respondents reported a fixed number of working hours per day and around $50 \%$ a fixed number of hours per week.

${ }^{5}$ The share of workers reporting negative health impact is significantly lower among agency workers, which might be associated with the small size of the sample and its youth. 
Aristovnik, A., \& Jaklič, K. (2013). Job satisfaction of older workers as a factor of promoting labour market participation in the EU: The case of Slovenia. Revija za socijalnu politiku, 20(2), 123-148. https://doi.org/ 10.3935/rsp.v20i2.1126

Arnoux-Nicolas, C., Sovet, L., Lhotellier, L., Di Fabio, A., \& Bernaud, J.-L. (2016). Perceived work conditions and turnover intentions: The mediating role of meaning of life and meaning of work. Frontiers in Psychology, 7, 704. https://doi.org/10.3389/fpsyg.2016.00704

Avolio, B. J., Zhu, W., Koh, W., \& Bhatia, P. (2004). Transformational leadership and organizational commitment: The mediating role of psychological empowerment and moderating role of structural distance. Journal of Organizational Behavior, 25(8), 951-968. https://doi.org/ $10.1002 /$ job.283

Blustein, D. L., Kenny, M. E., Di Fabio, A., \& Guichard, J. (2019). Expanding the impact of the psychology of working: Engaging psychology in the struggle for decent work and human rights. Journal of Career Assessment, 27(1), 3-28, https://doi.org/10.1177/1069072718774002

Burchell, B., Sehnbruch, K., Piasna, A., \& Agloni, N. (2014). The quality of employment and decent work: Definitions, methodologies, and ongoing debates. Cambridge Journal of Economics, 38(2), 459-477. https:// doi. org/10.1093/cje/bet067

Colbert, A. E., Bono, J. E., \& Purvanova, R. K. (2016). Flourishing via workplace relationships: Moving beyond instrumental support. Academy of Management Journal, 59(4), 1199-1223. https://doi.org/10.5465/ amj.2014.0506

Conigliaro, P. (2019). Decent work principles and job quality criteria to improve sustainable and equitable well-being. In A. Bianco, P. Conigliaro, \& M. Gnaldi (Eds.), Italian studies on quality of life. Social indicators research series, vol 77 (pp. 333-347). Springer. https://doi.org/ 10.1007/978-3-030-06022-0_22

Deakin, S. (2016). New forms of employment: Implications for EU law - The law as it stands. In R. Blanpain \& F. Hendrickx (Eds.), New forms of employment in Europe (pp. 43-53). Kluwer Law International.

Di Fabio, A., \& Maree, J. G. (2016). Using a transdisciplinary interpretive lens to broaden reflections on alleviating poverty and promoting decent work. Frontiers in Psychology, 7, 503. https://doi.org/ 10.3389/fpsyg.2016.00503

Domadenik, P., Bagari, S., Franca, V., Redek, T., \& Rihter, L. (2020). Empirična analiza prekarnosti na trgu dela v Sloveniji. (Empirical analysis of precariousness on the labour market in Slovenia.) In K. Kresal Šoltes, G. Strban, \& P. Domadenik, (Eds.), Prekarno delo: multidisciplinarna analiza (Precarious work: A multidisciplinary analysis) (pp. 263-280). Univerza v Ljubljani, Pravna fakulteta, Založba Pravne fakultete.

Duffy, R. D., Blustein, D. L., Diemer, M. A., \& Autin, K. L. (2016). The psychology of working theory. Journal of Counseling Psychology, 63(2), 127-148. https://doi.org/10.1037/cou0000140

Duffy, R. D., Allan, B. A., England, J. W., Blustein, D. L., Autin, K. L., Douglass, R. P., Ferreira, R., \& Santos, E. J. R. (2017). The development and initial validation of the Decent Work Scale. Journal of Counseling Psychology, 64(2), 206-221. https://doi.org/10.1037/cou0000191 
DRUŠ. ISTRAŽ. ZAGREB GOD. 30 (2021), BR. 4, STR. 655-674

ARZENŠEK, A. ET AL.: JOB AND...
Eurostat (2020). Statistical database. https://ec.europa.eu/eurostat/data/ database.

EWCS (2015). Sixth European Working Conditions Survey Microdata: 2015. https://www.eurofound.europa.eu/sr/surveys/european-working-con ditions-surveys/sixth-european-working-conditions-survey-2015

EWCS (2020). European Working Conditions Surveys (EWCS). https://www. eurofound.europa.eu/sr/surveys/european-working-conditions-surveys

Ferraro, T., dos Santos, N. R., Pais, L., \& Mónico, L. (2016). Historical landmarks of decent work. European Journal of Applied Business Management, 2(1), 77-96. https://www.researchgate.net/publication/3036 75107_Historical_landmarks_of_decent_work

Frankl, V. E. (1969). The will to meaning. New American Library.

Ghai, D. (2013). Decent work: Concepts and indicators. International Labour Review, 142(2), 113-145. https://doi.org/10.1111/j.1564-913X.2003. tb00256.x

Green, F. (2021). Decent work and the quality of work and employment, GLO Discussion Paper No. 817. Global Labor Organization (GLO).

Heaney, C. A., Israel, B. A., \& House, J. S. (1994). Chronic job insecurity among automobile workers: Effects on job satisfaction and health. Social Science \& Medicine, 38(10), 1431-1437. https://doi.org/10.1016/ 0277-9536(94)90281-X

Hvalič-Touzery, S., Babnik, K., Pivač, S., \& Skela-Savič, B. (2020). Measuring individual and work-related correlates of employees' well-being with a short form of the psychological general well-being index: A pilot validation study in Slovenia. Human Systems Management, 39(2), 265-275. https://doi.org/10.3233/HSM-190721

International Labor Organization (2017). Decent work. Http://www. ilo.org/global/topics/decent-work/lang--en/index.htm [Accessed 15 February 2021]

International Labor Organization (2018). Care work and care jobs: For the future of decent work. https://www.ilo.org/wcmsp5/groups/public/--dgreports/---dcomm/---publ/documents/publication/wcms_633135.pdf

Johnson, R. R. (2012). Police officer job satisfaction: A multidimensional analysis. Police Quarterly, 15(2) 157-176. https://doi.org/10.1177/ 1098611112442809

Judge, T. A., Piccolo, R. F., \& Ilies, R. (2004). The forgotten ones? The validity of consideration and initiating structure in leadership research. Journal of Applied Psychology, 89(1), 36-51. https://doi.org/10. 1037/0021-9010.89.1.36

Judge, T. A., Piccolo, T. F., Podsakoff, N. P., Shaw, J. C., \& Rich, B. L. (2010). The relationship between pay and job satisfaction: A meta-analysis. Journal of Vocational Behavior, 77(2), 157-167. https://doi.org/ 10.1016/j.jvb.2010.04.002

Kenner, J., Florczak, I., \& Otto, M. (2019). Precarious work. The challenge for labour law in Europe. Edward Elgar Publishing. https://doi.org/10. $4337 / 9781788973267$

Kinnunen, U., Mauno, S., Nätti, J., \& Happonen, M. (1999). Perceived job insecurity: A longitudinal study among Finnish employees. Euro- 
DRUŠ. ISTRAŽ. ZAGREB GOD. 30 (2021), BR. 4, STR. 655-674

ARZENŠEK, A. ET AL. JOB AND... pean Journal of Work and Organizational Psychology, 8(2), 243-260. https://doi. org/10.1080/135943299398348

Kozan, S., Işık, E., \& Blustein, D. (2019). Decent work and well-being among low-income Turkish employees: Testing the psychology of working theory. Journal of Counseling Psychology, 66(3), 317-327. https://doi. org/10.1037/cou0000342

Lysova, E. I., Blake A. A., Dik, B. J., Duffy, R. D., \& Steger, M. F. (2019). Fostering meaningful work in organizations: A multi-level review and integration. Journal of Vocational Behavior, 110, Part B, 374-389. https://doi.org/10.1016/j.jvb.2018.07.004

Mauno, S., Leskinen, E., \& Kinnunen, U. (2001). Multiwave, multi-variable models of job insecurity: Applying different scales in studying the stability of job insecurity. Journal of Organizational Behavior, 22(8), 919-937. https://doi.org/10.1002/job.122

Piasna, A., Sehnbruch, K., \& Burchell, B. (2020). Decent work: Conceptualization and policy impact. In W. Leal Filho, A. Azul, L. Brandli, A. Lange Salvia, \& T. Wall (Eds.) Decent work and economic growth. Encyclopedia of the UN sustainable development goals. Springer. https://doi. org/10.1007/978-3-319-71058-7_107-1

Şahin, M., \& Bayramoğlu, G. (2015). Decent work in the context of corporate social responsibility. Journal of Advanced Management Science, 3(2), 162-167. https://doi.org/10.12720/joams.3.2.162-167

Schein, E. H. (2010). Organizational culture and leadership (4th ed.). Jossey-Bass.

Sehnbruch, K., Burchell, B., Agloni, N., \& Piasna, A. (2015). Human development and decent work: Why some concepts succeed and others fail to make an impact. Development and Change, 46(2), 197-224. https://doi.org/10.1111/dech.12149

SORS (2017). Labor force survey microdata. SORS.

SORS (2020). SI-Stat database. https://pxweb.stat.si/SiStat

Stuart, F., Pautz, H., Crimin, S., \& Wright, S. (2016). What makes decent work? A study with low paid workers in Scotland - initial findings. Oxfam Scotland.

Sverke, M., Hellgren, J., \& Näswall, K. (2002). No security: A meta-analysis and review of job insecurity and its consequences. Journal of Occupational Health Psychology, 7(3), 242-264. https://doi.org/10.1037/ 1076-8998.7.3.242

Svetlik, I. (2004). Uvod: Razpoke v zgodbi o uspehu [Introduction: Cracks in the success story]. In I. Svetlik \& B. Ilič (Eds.), Razpoke v zgodbi o uspehu [Cracks in the success story] (pp. 1-12). Založba Sophia.

Tomaževič, N., Seljak, J., \& Aristovnik, A. (2014). Factors influencing employee satisfaction in the police service: The case of Slovenia. Personnel Review, 43(2), 209-227. https://doi.org/10.1108/PR-10-2012-0176 United Nations (2015). Handbook on measuring quality of employment A statistical framework. United Nations Economic Commission for Europe.

Vodopivec, M., Laporšek, S., \& Vodopivec, M. (2016). Levelling the playing field: The effects of Slovenia's labour market reform of 2013. IZA Discussion Paper No. 8793. Institute for the Study of Labor. 
DRUŠ. ISTRAŽ. ZAGREB GOD. 30 (2021), BR. 4, STR. 655-674

ARZENŠEK, A. ET AL.: JOB AND...
Wang, H., Tong, L., Takeuchi, R., \& George, G. (2016). Corporate social responsibility: An overview and new research directions. Thematic issue on corporate social responsibility [From the Editors]. Academy of Management Journal, 59(2), 534-544. https://doi.org/10.5465/amj.2016.5001

\section{Radni i organizacijski aspekti rada u Sloveniji}

Ana ARZENŠEK, Suzana LAPORŠEK

Fakultet za menadžment, Sveučilište Primorska,

Koper, Slovenija

Valentina FRANCA

Fakultet za upravu, Sveučilište u Ljubljani, Ljubliana, Slovenija

U svijetu je sve više nesigurnih radnih uvjeta koji utječu na tradicionalno marginalizirane skupine radnika. Isto tako, sve češće radnici srednje klase i viših slojeva osjećaju nesigurnosti na radnom miestu. Novi oblici rada doveli su do mnogih etičkih, psiholoških i pravnih dvojbi. U ovom članku analiziramo koncept pristojnog rada i usredotočujemo se na radne i organizacijske dimenzije rada u Sloveniji. Stoga se u empirijskom dijelu članka usredotočujemo na radno vrijeme, organizaciju rada i suradnju unutar timova, ravnotežu radnoga i privatnoga života, zdravlje i stres te ukupno zadovoljstvo radnim uvjetima. Rezultati pokazuju da novi oblici rada čine posao manje stabilnim i na taj način ugrožavaju dobrobit radnika, što je posebno izraženo u grupi mlađih radnika, agencijskih radnika i samozaposlenih u Sloveniji. Stoga treba razvijati mjere za rješavanje segmentacije tržišta rada koje će biti višeznačne i na više razina, uzimajući u obzir socijalne, psihološke i zakonodavne čimbenike, posebno ako je riječ o potrebama zaposlenih koji moraju raditi netipično.

Ključne riječi: pristojan rad, organizacijska psihologija, kvaliteta zaposlenosti, stanje na tržištu rada, Slovenija

\section{(c) (1) (9)}

Međunarodna licenca / International License:

Imenovanje-Nekomercijalno / Attribution-NonCommercial 